\title{
The Role of BDS-P in Gap Reducing SMEs and Large Enterprises in Indonesia
}

\author{
Khabib Alia Akhmad ${ }^{1}$, Ravik Karsidi ${ }^{1}$, Endang Siti Rahayu ${ }^{1}$, Mahendra Wijaya ${ }^{1}$ \\ ${ }^{1}$ University of Sebelas Maret, Surakarta, Indonesia
}

\begin{abstract}
Micro-, small-, and middle-scale Enterprises (SMEs) in Indonesia contribute substantially to national economy, however the existence of SMEs itself encounters problems inhibiting its performance and business capability; on the other hand, government gives limited help in dealing with many problems the SMEs encounter. The existence of Business Development ServiceProvider (BDS-P) is an alternative solution to help SMEs develop their business and reduce the gap between large enterprises and SMEs in the term of productivity, ability in accessing market, accessing information, using technology, and in accessing funding sources, so that SME can contribute to economic growth, job opportunity fulfillment, and poverty alleviation in Indonesia.
\end{abstract}

Keywords: BDS-P, SMEs, Large Enterprises, Gap

\section{Introduction}

Micro-, Small-, and Medium-scale Enterprises (SMEs) in Indonesia contribute substantially to national economy; monetary crisis in 1997 - 1998 has reopened the government's view on the importance of paying attention to SMEs, recalling that when crisis occurred SMEs were not affected too seriously and tended to survive. Before crisis in 1997, development orientation conducted by government should build on large enterprises or conglomerates aiming to pursue high growth, because with high growth, trickle down effect is expected to occur thereby accelerating the improvement of national income that will contribute to even distribution of income.

The change of economic development paradigm, so far building on large enterprises, was rearranged under President Habibie's reign post-reform. Sukidjo[1] stated that Government pays considerable attention to the development of SMEs since the 3rdFive-Year Plan (Pelita III). Those programs were developed continuously and in reform government, pro-people economic program was launched along with a number of credit schemes. However, in its realization up to 1997, government was still partial to large enterprises or conglomerates as characterized with many facilities given to large enterprises.

\section{Methodology}

This research employed qualitative method to understand in-depth the problem about the role of BDS-P in the attempt of reducing the gap between SMEs and large enterprises In Indonesia. The type of research used was descriptive qualitative one studying the problems existing and the work mechanism prevailing. This descriptive qualitative research was intended to describe what prevails currently. It contains the attempt of describing, recording, analyzing and interpreting the present condition. The instruments of research were observation, interview, and documentation.

The procedure taken in data analysis included: Data reduction involving sorting, concentrating, paying attention, simplifying, abstracting, and transforming raw data generated from field notes so that the data give clearer description about the result of observation, interview, and documentation; Data display constituting a set of information organized allowing for conclusion drawing and acting on. Through data display, the organized data would be more understandable; and finally conclusion or verification in which the author drew a conclusion based on the data processed through data reduction and display.

\section{Discussion}

Many experts and institutions define SMEs differently as the enterprises with small initial capital or small asset (wealth) value and small (limited) number of employees, capital (asset) or employee number consistent with the definition provided by government or other institutions with certain objective[2]. Corresponding to Law Number 20 of 2008 about Micro-, Small-, and Medium-scale Enterprises (SMEs), based on asset and sale volume,Micro-scale enterprise is the one with

*Corresponding author: khabib.1976@gmail.com 
maximum asset of 50 millions and maximum sale volume of 300 millions, Small-scale enterprise is the one with asset of 50 millions to 500 millions, while Medium-scale enterprise is the one with asset of 500 millions to 1 billions and sale volume of 2.5 billions to 50 billions.

The existence of SMEs in many developing countries is faced with the problems inhibiting its business performance and ability. Similarly, SMEs in Indonesia still face technical constraints hindering its business activity continuously such as: entrepreneurship, skill and ability, marketing, human resource management, and finance. Generally, the problems encountered by SMEs are: a. Limited ability of accessing market and expanding marketplace, b. Poor ability of accessing information, c. Poor ability of utilizing technology and sharing technology, d. Poor ability of accessing financial sources, particularly in banking loan, e. Low quality of human resource, and f. Poor organization and management ability.

The existence of SMEs also faces direct and indirect competition with Large Enterprises;many advantages the large enterprises have, including good abilities of managing and organizing business, technology mastery, broad access to financial source, and relatively good access to domestic market and export affect SME performers. Those problems cannot be solved by SME performers themselves; therefore facilitator, in this case BDS-P that understands better the problems of SMEs and gives solution to the problems, is required. The SME performers' inadequate skill also encourages the SMEs to need BDS-P.

The role of government in the attempt of solving many problems the SMEs encounter is an obligation the government should perform, but according to[3], out of a variety of partnerships that should be made by government and SME, government can perform only a few of partnership roles as mandated in Law No. 20 of 2008[4], and Government's scope over SMEs in making partnership is very limitedso far. The factors inhibiting the contribution of Government partnership to SMEs are: limited number and intellectual ability of government's apparatus resource, limited government budget, limited government apparatus' work infrastructure, inadequate integrity of government apparatus in working for community, and strong bureaucratic culture in government. In local area, the local government's work unit responsible for providing service to SMEs also faces classical problems such as limited human resource and its competency, limited budget, and limited work infrastructure. Illustratively, in every service catering to SMEs, there are no more than ten competent staffs generally. Meanwhile, there are thousands SMEs in every regency/municipal, so that it is impossible to cater them all[5].

Some difficulties the SMEs face can be solved with business development service. Business Development Service (thereafter called BDS) refers to a variety of nonfinancial service provided by community and private (BDS service provider) to SME performers in order to help them operate and develop their business efficiently and to contribute to economic growth, job opportunity, and poverty alleviation[6]. Therefore, the existence of
BDS aims to deal with many constraints above through training, consultation, marketing service, business information, business promotion for business relation, and other non-financial service. The existence of consultants is required by SMEs in order to help deal with some knowledge constraints and SMEs are highly dependent on the consultant's ability of dealing such the constraints (Thong[7]; Nevo et al[8]; Carey[9] and Chen et al[10]). Nahavandi and Chestern[11] stated that SMEs basically need consultant to give supportin the terms of information, operation and activity process due to SMEs' limited ability to develop their performer, while[12] in their study reveals the benefit of business support to SMEs.

Idea of Business Development Service (BDS)has begun since 1995, constituting the answer to SMEs development problem in non-financial aspect. Then, the idea was developed by Donor State Committee for small enterprise and Business Development Service work group was established. BDS pattern had entered into Indonesia since 1994 through a program developed by SwissContact through the establishment of WPU Bandung. In 2001, the blueprintconcept of Business Development Service was published through a series of studies in a conference in Harere, Rio and Hanoi between 1998 and 2000. In 2001, BPS-KPKM RI introduce the importance of BDS' role by involving BDS-P in developing 91 Small-and Medium-scale centers distributed to nearly all provinces of Indonesia ${ }^{13}$.

BDS is a non-financial service aiming to improve a company's performance, access to market and an individual company's competitive ability available in short term or temporarily. The service the Business Development Service gives to SMEs includes: information service, consultation, training, guiding/counseling, and organizing business contact and facilitation in expanding market, obtaining capitalization, organization and management development, technology development, and business development proposal organization[13]. RI's government regulation governing BDS-P participation contains some rules (RI's Cooperative and SME Ministry): a. Republic of Indonesia's Law Number 20 of 2008 governing about Micro-, Small-, and Medium-scale Enterprises4, b. Republic of Indonesia's State Minister for Cooperatives and SMEs Number 02/Per/M.KUKM/I/2008 governing the Guidelines of Business Development ServicesProvider(BDS-P) empowerment to develop Cooperatives, Micro-, Small-, and Medium-scale Enterprises[14], c. Deputy of Cooperatives and SMEs Minister's Regulation for Business Development and Restructuring Number 03/Per/Dep.6/VIII/2014 01/Per/Dep.6/I/2014 about the Amendment to Deputy of Cooperatives and SMEs Minister's Regulation for Business Development and Restructuring Number01/Per/Dep.6/I/2014 dated on January 30, 2014 about Technical Instruction of Social Grant for Cooperatives and Micro,- Small-, and Mediumscale enterprises in Business Development and Restructuring field, containing an explanation about incentive grant for LPB/BDS-P[15], and d. RI's Cooperatives and Micro,- Small-, and Medium-scale enterprises Minister Regulation Number 
07/Per/M.KUKM/VII/2015 about Strategic Plan of RI's Cooperatives and Micro,- Small-, and Medium-scale enterprises Ministry in 2015-2019 revealing theachievement of ministry's performance target in which 1,218 persons attend the improvement of capacity for LPB/BDS-P facilitation institution[16].

The result of[17] study shows that small-scale enterprise will be prosperous when it is supported with BDS focusing on the problems faced by the enterprise, even BDS use has been recognized as academicians and policy makers as a method that can be used to improve the performance of small enterprise (Bennett and Robson[18] ; Massey[19] ; Chrisman and McMullan[20] ; and Ramsden and Bennett[21]). In Indonesia, some studies related to the role of BDS-P have been conducted, among others, by[22] concluding that BDS-P plays significant role in facilitating SMEs to acquire capital and to expand marketplace. Putri, Pradhanawarti and Prabawani[23] concluding that BDS-P's contribution to SMEs development has been proved, and Fauzi[24] suggesting that BDS-P serving as an institution providing SME development service obligatorily has service programs in line with SME development fields that have been governed in government regulation.

\section{Conclusion}

With the limitation the government has, BDS-P plays a sufficiently significant part in developing SMEs in Indonesia, because some constraints faced by SMEs can be dealt with by the service provided by BDS-P. A variety of training and facilitation activities conducted by BDS-P for SME performers can help reduce the gap between large enterprises and SMEs in the term of productivity, ability of accessing market, accessing information, mastering technology, and accessing funding sources. The role of BDS-P in the world of enterprises in order to help SMEs. Where the problem of SMEs the level of knowledge about the environment is not good enough, especially in developing countries such as Indonesia. So it is hoped that this can be helped but can still be responsible for the environment and be environmentally friendly. Finally, SMEs can operate efficiently and develop their business with broader objective, in this case contributing to economic growth, job opportunity fulfillment and poverty alleviation.

\section{References}

1. Sukidjo, "Strategi Pemberdayaan Usaha Kecil dan Menengah", Jurnal Ekonomi \& Pendidikan, Volume 2, Nomor 1, Agustus (2004).

2. S. Sukirno, "Makroekonomi Teori Pengantar", Rajawali Pers, Jakarta (2004).

3. Trimurti and C. Purnama, "Peran Pemerintah Dalam Kemajuan Umkm Di Indonesia" .http://lppm.unmas.ac.id/wpcontent/uploads/2014/06/43-CHRISTIMULIAKL1.pdf (2013).
4. Republic of Indonesia's Law Number 20 of 2008 governing about Micro-, Small-, and Mediumscale Enterprises (2008).

5. Local Governance Support Program (LGSP), "Seri Manajemen Pelayanan Publik. Praktekpraktek yang baik dalam Pemberdayaan UKM" (2009).

6. A. O. Miehlbradt and M. McVay, "Seminar Reader - Developing Commercial Markets for BDS Update, Fourth Annual BDS Seminar Turin, Italy, ILO, Small Enterprise Development Programme of the International Labour Organisation", http://www.ilo.org/empent/Publications/WCMS _143127/lang--en/index.html (2003).

7. J. Y. L. Thong, "Resource Constraints And Information Systems Implementation In Singaporean Small Businesses", Omega, 29(2): 143-156. DOI: 10.1016/S0305- 0483(00)000359 (2001).

8. S. Nevo, M. R. Wade \& W. D. Cook, "An Examination Of The Trade-Off Between Internal And External IT Capabilities", Journal of Strategic Information Systems, 16(1): 5-23. DOI: 10.1016/j.jsis.2006.10.002 (2007).

9. C. Janene, "Role Misconceptions And Negotiations In Small Business Owner/Web Developer Relationships", Journal of Management \& Organization, 14(1): 85-99 (2008).

10. R.-S. Chen, W.-J. Jih, C.-M. Sun, \& M.M. Helms, "Role Negotiation and Interaction: An Exploratory Case Study of the Impact of Management Consultants on ERP System Implementation in SMEs in Taiwan", Information Systems Management, 25(2): 159173. DOI: 10.1080/10580530801941371 (2008).

11. A. Nahavandi \& S. Chesteen, "The Impact of Consulting on Small Business: A Further Examination. Entrepreneurship Theory and Practice", 13, pp. 29-40 (1998).

12. C. Wren and D. J. Storey, "Evaluating The Effect Of Soft Business Support Upon Small Firm Performance", Oxford Economic Papers, 54, 334-365. http://dx.doi.org/10.1093/oep/54.2.334 (2002).

13. S. Soetrisno, "Sambutan Ketua Umum Asosiasi BDS" (2002).

14. Republic of Indonesia's State Minister for Cooperatives and SMEs Number 02/Per/M.KUKM/I/2008 governing the Guidelines of Business Development ServicesProvider(BDS-P) empowerment to develop 
Cooperatives, Micro-, Small-, and Mediumscale Enterprises (2008).

15. Deputy of Cooperatives and SMEs Minister's Regulation for Business Development and Restructuring Number 03/Per/Dep.6/VIII/2014 01/Per/Dep.6/I/2014 about the Amendment to Deputy of Cooperatives and SMEs Minister's Regulation for Business Development and Restructuring Number01/Per/Dep.6/I/2014 dated on January 30, 2014 about Technical Instruction of Social Grant for Cooperatives and Micro,- Small-, and Medium-scale enterprises in Business Development and Restructuring field, containing an explanation about incentive grant for LPB/BDS-P (2014).

16. RI's Cooperatives and Micro,- Small-, and Medium-scale enterprises Minister Regulation Number 07/Per/M.KUKM/VII/2015 about Strategic Plan of RI's Cooperatives and Micro,Small-, and Medium-scale enterprises Ministry in 2015-2019

17. B. P. Van, "Business support and the importance of business networks", Small Enterprise Development, 9(4) (1998).

18. R. J. Bennett and P. J. A. Robson, "The Use Of External Business Advice By Smes In Britain”, Entreprenership and Regional Development 11 (1999).

19. C. Massey, "Enterprise Assistance: Response From The Public And Private Sectors. Journal of
Small Business and Enterprise Development", 10 (2), 128-135 (2003).

20. J. J. Chrisman and W. E. McMullan, "Outsider Assistance As A Knowledge Resource For New Venture Survival", Journal of Small Business Management, 42, 229-244 (2004).

21. M. Ramsden and R. J. Bennett, "The Benefits Of External Support To Smes: "Hard" Versus "Soft" Outcomes And Satisfaction Levels H. Matlay", ed. Journal of Small Business and Enterprise Development, 12(2), pp.227-243 (2005).

22. N. Imamah, "Peranan Business Development Service dalam Pengembangan Usaha Kecil Menengah di Wedoro Centre" (2008).

23. K. Putri, A. Pradhanawarti and B. Prabawani, "Pengaruh Karakteristik Kewirausahaan, Modal Usaha Dan Peran Business Development Service Terhadap Pengembangan Usaha (Studi Pada Sentra Industri Kerupuk Desa Kedungrejo Sidoarjo Jawa Timur)", Jurnal Ilmu Administrasi Bisnis, Volume 3, Nomor 4 (2014).

24. R. A. Fauzi . "Analisis Keselarasan Program Layanan Business Development Service Provider BDS-P Terhadap Peraturan Pemerintah Terkait Pengembangan UMKM di Jawa Timur", Undergraduate Theses of Industrial Engineering, RSI 658.562 Fau a (2014). 